\title{
Expression of the Alpha-1-Antitrypsin Gene in Mononuclear Phagocytes of Normal and Alpha-1-Antitrypsin-deficient Individuals
}

\author{
Jean-Francois Mornex, Anna Chytil-Weir, Yves Martinet, Michael Courtney, Jean-Pierre LeCocq, and Ronald G. Crystal \\ Pulmonary Branch, National Heart, Lung, and Blood Institute, National Institutes of Health, \\ Bethesda, Maryland 20892; and Transgene SA, 67000 Strasbourg, France
}

\begin{abstract}
To evaluate the contribution of mononuclear phagocytes, and particularly alveolar macrophages, to alpha-1-antitrypsin ( $\alpha 1 \mathrm{AT})$ production in normal and $\alpha 1$ AT-deficient individuals, Northern analysis with a human $\alpha 1$ AT complementary DNA was used to demonstrate that $\alpha 1 A T$ messenger RNA (mRNA) can be detected in liver, blood monocytes, and alveolar macrophages. Quantification of $\alpha 1$ AT mRNA expression demonstrated that: (a) type PiMM monocytes and alveolar macrophages expressed, respectively, 200-fold and 70-fold less $\alpha 1 A T$ mRNA per cell than the liver; (b) the level of expression of the $\alpha 1 \mathrm{AT}$ gene was increased during the in vitro maturation of blood monocytes; and (c) blood monocyte and alveolar macrophage levels of expression of the $\alpha 1$ AT gene were the same in PiMM and PiZZ individuals. However, the amount of newly synthesized $\alpha 1 \mathrm{AT}$ secreted by $\mathrm{ZZ}$ alveolar macrophages was 10 times lower than that secreted by MM alveolar macrophages. Thus, mononuclear phagocytes of PiZZ individuals express a secretory defect in $\alpha 1 \mathrm{AT}$ in a fashion similar to hepatocytes. Not only do mononuclear phagocytes provide a readily accessible cell to evaluate the regulation of $\alpha 1 \mathrm{AT}$ gene expression, but these cells may contribute to the levels of $\alpha 1 \mathrm{AT}$ present in the lower respiratory tract in the normal and $\mathrm{ZZ}$ states.
\end{abstract}

\section{Introduction}

Alpha-1-antitrypsin ( $\alpha 1 \mathrm{AT}),{ }^{1}$ a 52,000-D serum glycoprotein, is the major inhibitor of neutrophil elastase, a destructive enzyme capable of cleaving all of the major connective tissue components of the extracellular matrix of most tissues (1-5). The primary site of action of $\alpha 1 \mathrm{AT}$ is the lower respiratory tract, where it protects the alveolar walls against destruction and hence emphysema (1-3, 6-10). When the serum level of $\alpha 1$ AT is below $80 \mathrm{mg} / \mathrm{dl}$ (normal $150-350 \mathrm{mg} / \mathrm{dl}$ ), as occurs in the hereditary disorder of $\alpha 1 \mathrm{AT}$ deficiency, there is insufficient $\alpha 1 \mathrm{AT}$ in the lower respiratory tract to inhibit the burden of elastase, and the affected individual develops emphysema, usually in the third to fourth decade (1-10).

The human $\alpha 1 \mathrm{AT}$ gene is present in a single 10.2-kilobase

Dr. Mornex's present address is Hôpital Louis Pradel, 69394 Cedex 3, Lyon, France. Address reprint requests to Dr. Crystal, Building 10, Room 6D03, National Institutes of Health, Bethesda, MD 20892. 1986.

Received for publication 10 June 1985 and in revised form 24 February

1. Abbreviations used in this paper: $\alpha 1 \mathrm{AT}$, alpha-1-antitrypsin; DME, Dulbecco's modified Eagle's medium; FBS, fetal bovine serum; kb, kilobase; $\mathrm{Pi}$, protease inhibitor.

The Journal of Clinical Investigation, Inc.

Volume 77, June 1986, 1952-1961 (kb) segment of DNA on chromosome 14 (11-13). At least 30 $\alpha 1 \mathrm{AT}$ haplotypes are known and the $\alpha 1 \mathrm{AT}$ phenotype is conventionally categorized with the Pi ("protease inhibitor") system by isoelectric focusing of serum at $\mathrm{pH} 4.0-5.0(2,14)$. Most individuals with normal amounts of $\alpha 1 \mathrm{AT}$ in the serum are homozygous or heterozygous for various $M$ haplotypes (M1, M2, M3), while most of $\alpha 1$ AT-deficient individuals are homozygous for the $Z$ haplotype (glu ${ }^{342}$ to lys $\left.^{342}\right)(1-4,15,16)$.

The liver is known to be a major source of $\alpha 1 \mathrm{AT}$ : isolated perfused liver, fragments of liver, hepatoma cell lines, and diploid hepatocytes in culture all produce $\alpha 1 \mathrm{AT}$ (17-22). Furthermore, liver $\alpha 1 \mathrm{AT}$ mRNA has been translated in vitro, has been used to direct Xenopus oocytes to produce $\alpha 1 \mathrm{AT}$, and has been used to produce $\alpha$ IAT cDNA (23-32). In the common PiZZ form of $\alpha 1 \mathrm{AT}$ deficiency, it is hypothesized that the decreased plasma (and hence lung) levels of $\alpha 1 \mathrm{AT}$ result from an inability of the $\alpha 1 \mathrm{AT}$ protein to be secreted by the hepatocyte $(4,25-27,33$, 34). Although the mechanism is not completely proven, it is thought to result from an abnormally slow rate of folding of the $\mathrm{Z}$ protein within the rough endoplasmic reticulum in such a way that the newly synthesized protein does not move at a normal rate to the Golgi complex $(4,35)$. As a result, the three carbohydrate side chains added in the rough endoplasmic reticulum to asparaginyl residues at positions 46,83 , and 247 are not trimmed appropriately, leaving high-mannose carbohydrates attached to the $\mathrm{Z}$ protein that accumulates in the rough endoplasmic reticulum $(4,15,16,36)$.

In addition to the hepatocytes, it is also known that cells of the mononuclear series, including monocytes, alveolar macrophages, and breast milk macrophages all produce $\alpha 1 \mathrm{AT}$ (27, $37-46)$. Because the level of $\alpha 1 \mathrm{AT}$ produced by these cells is thought to be quite low, mononuclear phagocytes have been generally ignored as playing a relevant role in the normal physiology of $\alpha 1 \mathrm{AT}$ or in the pathogenesis of the decreased amounts of $\alpha 1 \mathrm{AT}$ found in the PiZZ form of $\alpha 1 \mathrm{AT}$ deficiency. Such a view, however, may be naive. There are large numbers of mononuclear phagocytes in the body, probably at least $50 \times 10^{9}$ cells (alveolar macrophages, $20 \times 10^{9}$; bone marrow, $8 \times 10^{9}$; blood monocytes, $2 \times 10^{9}$; Kupfer cells, $\left.20 \times 10^{9}\right)(47-50)$. Although this is lower than the estimated $180 \times 10^{9}$ hepatocytes in the normal adult liver (50), it is important to remember that: $(a)$ alveolar macrophages, the mononuclear phagocytes of the lower respiratory tract, are located directly at the site where $\alpha 1 \mathrm{AT}$ plays its major role as an antineutrophil elastase and where $\alpha 1 \mathrm{AT}$ deficiency manifests; and (b) alveolar macrophages represent $\sim 10 \%$ of the cells of the alveolar structures and are constantly renewed by the circulating monocyte pool and by replication in the local milieu $(47,51,52)$.

In this context, the present study was designed to evaluate the potential of human mononuclear phagocytes to produce $\alpha 1 \mathrm{AT}$ by quantifying $\alpha 1 \mathrm{AT}$ messenger RNA (mRNA) levels in blood monocytes and alveolar macrophages and by comparing 
these levels to that in the liver. Furthermore, because $\alpha 1 \mathrm{AT}$ deficiency is a disease in which lung $\alpha$ lAT levels are markedly decreased, alveolar macrophages from normal (PiMM) and $\alpha 1 \mathrm{AT}$-deficient (PiZZ) individuals were compared. Interestingly, although $\alpha 1 \mathrm{AT}$ mRNA levels in blood monocytes are $0.5 \%$ that of the liver cells, normal alveolar macrophages have threefold more $\alpha 1$ AT mRNA per cell than do monocytes. Furthermore, alveolar macrophages of PiZZ and PiMM individuals have similar quantities of $\alpha 1 \mathrm{AT}$ mRNA per cell, yet the PiZZ alveolar macrophages secrete less, suggesting that the secretory defect observed in the liver may be general for all cell types expressing the $\alpha 1 \mathrm{AT}$ gene.

\section{Methods}

\section{Study population}

Two groups of individuals were evaluated: normals and those with PiZZ $\alpha 1 \mathrm{AT}$ deficiency. Diagnosis of PiZZ-type $\alpha 1 \mathrm{AT}$ deficiency was made by a combination of measurement of serum $\alpha 1 \mathrm{AT}$ levels determined by radial immunodiffusion (Calbiochem-Behring Corp., La Jolla, CA), Pi type by isoelectric focusing of serum, and family studies by demonstrating codominant inheritance $(2,14,53,54)$. The normal individuals $(n=35)$ all had normal $\alpha 1 \mathrm{AT}$ serum levels $(203 \pm 15 \mathrm{mg} / \mathrm{dl}$, range $124-340 \mathrm{mg} /$ dl [all data in this article are presented as mean \pm standard error of the mean]), and all were of phenotype PiMM (i.e., various combinations of haplotypes M1, M2, and M3). This group consisted of 13 males and 22 females, age 40 $\pm 3 \mathrm{yr}$ (range 27-60) and included 23 nonsmokers and 12 smokers ( $23 \pm 9$ pack-year). The $\alpha 1 \mathrm{AT}$-deficient group included 13 individuals (Table I). All had serum $\alpha 1 \mathrm{AT}$ levels below $50 \mathrm{mg} / \mathrm{dl}(31 \pm 3$ $\mathrm{mg} / \mathrm{dl}$, range $20-41 \mathrm{mg} / \mathrm{dl}$ ) and all had emphysema as defined by conventional criteria (55).

\section{Cell types evaluated}

The cells evaluated included normal human liver, a human hepatoma cell line (SK-HEP-1), a human fetal liver cell line (CLCL), normal (PiMM) blood monocytes, normal (PiMM) blood lymphocytes, normal (PiMM) blood neutrophils, normal (PiMM) alveolar macrophages, PiZZ $\alpha 1$ ATdeficient blood monocytes, PiZZ $\alpha 1$ AT-deficient alveolar macrophages,

Table I. Clinical Features of Patients with a1AT Deficiency

\begin{tabular}{lc}
\hline Parameter & Value \\
\hline$n$ & 13 \\
Male/female & $11 / 2$ \\
Age $(y r)$ & $42 \pm 2$ (range $33-49)$ \\
Smoking status & \\
$\quad$ Nonsmokers $(n)$ & 1 \\
$\quad$ Ex-smokers $(>2$ yr $)(n)$ & $9(25 \pm 7$ pack-yr) \\
$\quad$ Current smokers $(n)$ & $3(20 \pm 5$ pack-yr) \\
Vital capacity & $74 \pm 7 \%$ predicted \\
Total lung capacity* & $100 \pm 5 \%$ predicted \\
FEV1 $¥$ & $51 \pm 8 \%$ predicted \\
FEV1/FVC $\$$ & $55 \pm 4 \%$ observed \\
& $73 \pm 5 \%$ predicted \\
DLCO & $50 \pm 6 \%$ predicted \\
\hline
\end{tabular}

See Fulmer et al. (100) for methods and predicted values.

* Helium dilution.

₹ Forced expiratory volume (FEV) in $1 \mathrm{~s}$.

$\S$ FEV1/forced vital capacity.

"Single breath diffusing capacity for carbon monoxide, predicted

based on volume and corrected for hemoglobin. a mononuclear phagocyte cell line (U-937), and human lung fibroblasts (HFL-1).

Liver cells. Normal human liver was obtained 12-24 h after death and quickly frozen. The hepatoma cell line SK-HEP-1 (56) and the fetal liver cell line CLCL (57) were obtained from the American Type Culture Collection (ATCC, Rockville, MD; SK-HEP-1 ATCC HTB52, CLCL ATCC CL99) and cultured in Dulbecco's modified Eagle's medium (DME) with 10\% heat-inactivated fetal bovine serum (FBS; Whittaker, M. A. Bioproducts, Walkersville, $\mathrm{MD}$ ) at $37^{\circ} \mathrm{C}$ in $90 \%$ air $/ 10 \% \mathrm{CO}_{2}$ until confluence.

Blood cells. Blood cells were obtained from heparinized venous blood, buffy coat preparations, and leukophoresis. Blood was fractionated by density-gradient centrifugation (LSM, Litton Bionetics, Kensington, MD) into mononuclear cells and granulocytes. Monocytes were purified from the mononuclear cell layer by adherence to plastic in RPMI-1640 medium with $10 \% \mathrm{FBS}, 1 \mathrm{~h}, 37^{\circ} \mathrm{C}$ as described by Johnson et al. (58). The monocytes were $>70 \%$ pure as assessed by morphology and nonspecific esterase staining (59). Lymphocytes were purified from the nonadherent mononuclear cells using an additional overnight adherence step at $37^{\circ} \mathrm{C}$ in RPMI-1640 (Whittaker, M. A. Bioproducts) with 10\% FBS; the nonadherent cells were $>90 \%$ pure lymphocytes. Neutrophils were purified from the pellet of the buffy coat density-gradient centrifugation by sedimentation on Plasmagel (Cellular Products, Buffalo, NY). The resulting neutrophil preparation was $>95 \%$ pure as shown by morphology after staining with Diff Quik (American Scientific Products, McGaw Park, IL).

Alveolar macrophages. Alveolar macrophages were obtained by bronchoalveolar lavage using a total of $300 \mathrm{ml}$ of saline as five $20-\mathrm{ml}$ aliquots in each of three sites as previously described (60). Cell differentials were determined using filter preparations as described by Saltini et al. (61). Samples were utilized only if the return of the infused saline was $>20 \%$, and if the contamination by bronchial cells was below $5 \%$. In all cases bronchoalveolar lavage cell suspension was composed of $>70 \%$ macrophages $(84 \pm 2 \%)$ and $<10 \%$ neutrophils $(3 \pm 5 \%)$. The viability of alveolar macrophages as assessed by blue trypan exclusion was $>90 \%$ in all cases.

Mononuclear phagocyte cell line. U-937, a human monocyte-like cell line (ATCC CRL1593) was cultured in RPMI-1640 with $10 \%$ FBS, at $37^{\circ} \mathrm{C}$, in $95 \%$ air $/ 5 \% \mathrm{CO}_{2}$, at a density of $0.5 \times 10^{6} \mathrm{cells} / \mathrm{ml}(62)$.

Human lung fibroblasts. The human fetal lung fibroblasts strain HFL1 (ATCC CCL153) was grown in DME with $10 \% \mathrm{FBS}$ at $37^{\circ} \mathrm{C}$ with $90 \%$ air $/ 10 \% \mathrm{CO}_{2}$, until confluence (63).

\section{Extraction of total cellular RNA}

Total cellular RNA was extracted from liver tissue by treatment with guanidine thiocyanate and repeated guanidine hydrochloride extractions (64). RNA was extracted from all other cell samples by treatment with guanidine hydrochloride and cesium chloride centrifugation $(65,66)$.

To avoid ribonuclease contamination, all reactions were performed in sterile plasticware or in glassware treated with $0.1 \%$ diethyl pyrocarbonate for $20 \mathrm{~min}$ and heated to $250^{\circ} \mathrm{C}$ overnight $(67,68)$. All reagents utilized molecular biology grade chemicals, free of ribonuclease activity (Bethesda Research Laboratories, Gaithersburg, MD, or International Biotechnologies, New Haven, CT) and were (including distilled deionized water), filtered on $0.22-\mu \mathrm{m}$ filters (Falcon Labware, Becton, Dickinson \& Co., Oxnard, CA), then treated with $0.1 \%$ diethyl pyrocarbonate and autoclaved. Formamide (Fluka AG, Buchs, Switzerland) was deionized on mixed bed resin (AG501-X8; Biorad Laboratories, Richmond, CA) at $4^{\circ} \mathrm{C}$ and its purity was assessed by a conductivity $<20 \mu \mathrm{S}(69)$. As a final protection against ribonucleases, all samples were washed in phosphate-buffered saline (PBS, Whittaker, M. A. Bioproducts) containing $10 \mathrm{mM}$ vanadyl ribonucleoside complex (Bethesda Research Laboratories) and $50 \mu \mathrm{g} / \mathrm{ml}$ cycloheximide, prior to extraction (70).

Liver tissue samples were pulverized in liquid nitrogen using a Polytron (Brinkmann Instruments Co., Westbury, NY) and then blended with $4 \mathrm{M}$ guanidine thiocyanate, $3.6 \mathrm{M}$ sarkosyl, $25 \mathrm{mM}$ sodium citrate (pH 7.0), $15 \mathrm{mM}$ 2-mercaptoethanol, and $0.1 \%$ (vol/vol) antifoam-A (16 ml/g of tissue). After centrifugation $\left(10,000 \mathrm{~g}, 10 \mathrm{~min}, 10^{\circ} \mathrm{C}\right.$ ) and addition of $0.025 \mathrm{vol}$ of $1 \mathrm{M}$ acetic acid to the supernatant, the RNA 
was precipitated with $0.75 \mathrm{vol}$ of $95 \%$ (vol/vol) ethanol $\left(-20^{\circ} \mathrm{C}, 16 \mathrm{~h}\right.$ ). The precipitate was recovered by centrifugation $\left(6,000 \mathrm{~g}, 10 \mathrm{~min}, 4^{\circ} \mathrm{C}\right)$ and dissolved in half the starting volume of $8 \mathrm{M}$ guanidine hydrochloride, $5 \mathrm{mM}$ dithiothreitol, and $25 \mathrm{mM}$ sodium citrate, $\mathrm{pH}$ 7.0. RNA was precipitated in $25 \mathrm{mM}$ acetic acid and $50 \%$ (vol/vol) ethanol $\left(-20^{\circ} \mathrm{C}\right.$, $3 \mathrm{~h}$ ). After centrifugation and dissolution in one fourth of the starting volume of $8 \mathrm{M}$ guanidine hydrochloride, $5 \mathrm{mM}$ dithiothreitol, and 25 $\mathrm{mM}$ sodium citrate, $\mathrm{RNA}$ was ethanol-precipitated. The pellet was washed in ethanol and dissolved in water.

Cells were lysed as a pellet or on tissue culture plates in $6 \mathrm{M}$ guanidine hydrochloride $\left(5 \mathrm{ml} / 10^{8}\right.$ cells). After addition of $0.1 \mathrm{vol}$ of $2 \mathrm{M}$ potassium acetate, pH 5.0, the cell lysate was shaken vigorously for 5-10 $\mathrm{min} .2$ vol of $7.2 \mathrm{mM}$ sarkosyl, $100 \mathrm{mM}$ Tris- $\mathrm{HCl}, \mathrm{pH} 8.0$, and $1 \mathrm{~g}$ of cesium chloride per $2.5 \mathrm{ml}$ were added, and the cell lysate was layered on a cushion of $5.7 \mathrm{M}$ cesium chloride, 0.1 M EDTA, pH 8.0, and the gradient was centrifuged at $25^{\circ} \mathrm{C}$ in SW41 rotor, $32,000 \mathrm{rpm}, 43 \mathrm{~h}$ or SW60 rotor, 44,000 rpm, $22 \mathrm{~h}$, or TLS 100 rotor, 43,000 rpm, $18 \mathrm{~h}$ (Beckman Instruments, Inc., Palo Alto, CA); the parameters of the centrifugation were chosen to pellet all cellular RNA. The pellet was dissolved in 100 $\mathrm{mM} \mathrm{NaCl}, 10 \mathrm{mM}$ Tris $\mathrm{HCl}, \mathrm{pH}$ 7.6, 1 mM EDTA, $17 \mathrm{mM}$ sodium dodecyl sulfate (SDS) and precipitated with ethanol. The yield of the extraction procedure was 75-100\%. All RNA samples were characterized as having intact $18 \mathrm{~S}$ and $28 \mathrm{~S}$ ribosomal RNA by acridine orange staining (see below) and were dissolved in water $(1 \mathrm{mg} / \mathrm{ml})$ and stored in liquid nitrogen vapor.

\section{Northern analysis}

Total cellular RNA was fractionated according to its molecular weight by electrophoresis in $1 \%$ agarose gel in denaturing conditions (71). The gels were run at $3 \mathrm{~V} / \mathrm{cm}$ for $4-6 \mathrm{~h}$ with buffer recirculation. RNA was denatured at $56^{\circ} \mathrm{C}, 15 \mathrm{~min}$ in $10 \mathrm{mM}$ sodium phosphate, $\mathrm{pH} \mathrm{7.0,50 \%}$ formamide, and $2.2 \mathrm{M}$ formaldehyde. Gel and electrophoresis buffers contained $10 \mathrm{mM}$ sodium phosphate, $\mathrm{pH} 7.0$, and $2.2 \mathrm{M}$ formaldehyde. Gels were stained with acridine orange $(30 \mu \mathrm{g} / \mathrm{ml}$ in $10 \mu M$ sodium phosphate buffer, $\mathrm{pH}$ 7.0) destained $1 \mathrm{~h}$ and examined with ultraviolet light (72). Transfer to nitrocellulose filter (BA85, Scheicher \& Schuell, Inc., Keene, NH $)$ in $20 \times \mathrm{SSC}(1 \times \mathrm{SSC}=150 \mathrm{mM} \mathrm{NaCl}, 15 \mathrm{mM} \mathrm{Na}$ citrate, $\mathrm{pH}$ 7.0) and baking were performed according to Thomas (73). The molecular weights of the mRNAs examined were determined according to their migration relative to DNA and RNA markers $(71,72)$. To accomplish this, $\lambda$ Hind III fragments (Bethesda Research Laboratories) were labeled with $\left[\gamma_{-}{ }^{32} \mathrm{P}\right] \mathrm{ATP}(5,400 \mathrm{Ci} / \mathrm{mmol}$, Amersham Corp., Arlington Heights, IL) by $5^{\prime}$ end-terminus labeling. There was similar migration of labeled and unlabeled $\lambda$ Hind III fragments and RNA markers (23 S and $16 \mathrm{~S}$ ribosomal RNA from Escherichia coli, Boehringer Mannheim, Indianapolis, IN; 28 S and 18 S RNA from human placenta, Pharmacia, PL Biochemicals, Piscataway, NJ).

\section{Complementary (cDNA) probes} and hybridization conditions

$\alpha 1 \mathrm{AT}$ mRNA was detected using a full-length human $\alpha 1 \mathrm{AT}$ cDNA clone (plasmid pTG603) previously described (31). Actin mRNA was detected using a human fibroblast cytoplasmic $\gamma$-actin cDNA (plasmid pHF $\gamma \mathrm{A}$ 1) kindly provided by P. Gunning and L. Kedes (Stanford University) (74). Both probes were nick translated with [ $\left.{ }^{32} \mathrm{P}\right] \mathrm{CTP}(3,000 \mathrm{Ci} / \mathrm{mmol}$, Amersham Corp.), and the labeled cDNA was purified using NACS Prepac (Bethesda Research Laboratories). This procedure yielded labeled probes with an activity $>10^{8} \mathrm{dpm} / \mu \mathrm{g}$. As a control for nonspecific hybridization, the plasmid pBR322 without the insert was also labeled in a similar fashion.

Prehybridization was conducted at $42^{\circ} \mathrm{C}, 6 \mathrm{~h}$, in $50 \%$ formamide, 5 $\times$ SSC, $50 \mathrm{mM}$ sodium phosphate, $\mathrm{pH} 7.0,10 \times$ Denhardt's solution $(0.2 \% \mathrm{wt} / \mathrm{vol}$ of each of the following: Ficoll 400 , polyvinylpyrrolidone, bovine serum albumin), $0.1 \%$ SDS, and $250 \mu \mathrm{g} / \mathrm{ml}$ denatured salmon sperm DNA (75). Hybridization was carried out in $4 \mathrm{vol}$ of the same buffer and 1 vol of $50 \%$ dextran sulfate at $37^{\circ} \mathrm{C}$ for $18 \mathrm{~h}(75)$. The filters were washed four times for $5 \mathrm{~min}$ in $2 \times \mathrm{SSC}, 0.05 \%$ disodium pyrophosphate, at $25^{\circ} \mathrm{C}$ and four times for $30 \mathrm{~min}$ in $0.1 \times \mathrm{SSC}, 0.05 \%$ sodium pyrophosphate, at $65^{\circ} \mathrm{C}$. Autoradiograms were performed with intensifying screen at $-80^{\circ} \mathrm{C}$. In some instances, repeated hybridization was carried out by removing the probe by two washes with boiled distilled water and one wash at $65^{\circ} \mathrm{C}$, for $4 \mathrm{~h}$, in $5 \mathrm{mM}$ Tris $\mathrm{HCl}, \mathrm{pH} 8.0,0.2$ mM EDTA, and $0.1 \times$ Denhardt's $(73,75)$.

\section{Quantitative evaluation of the expression of the $\alpha 1 A T$ gene}

Quantification of the expression of the $\alpha 1 \mathrm{AT}$ gene by liver, blood monocytes, and alveolar macrophages was performed using two methods: RNA dot-blot hybridization and Quick-blot.

For RNA dot-blot hybridization, total cellular RNA was denatured at $56^{\circ} \mathrm{C}, 15 \mathrm{~min}$ in $7.5 \times \mathrm{SSC}, 4.4 \mathrm{M}$ formaldehyde and applied to nitrocellulose filter with a Minifold Apparatus (Schleicher \& Schuell). The filter was then baked for $2 \mathrm{~h}$, at $80^{\circ} \mathrm{C}$ and hybridized as described above. The amount of specific hybridization was determined by scanning densitometry of the autoradiograms (Ortec, Oak Ridge, TN). Results were obtained as densitometric units per microgram of RNA. In order to express the results as units per cell, an aliquot of tissue or cell samples was used to measure the amounts of RNA (orcinol reaction) and DNA (diphenylamine reaction) after sodium hydroxide extraction and a value of $10 \mu \mathrm{g}$ of DNA $/ 10^{6}$ cells was used (76-79).

To assess the expression of the $\alpha 1 \mathrm{AT}$ gene in small cell samples, the Quick-blot method was used as described by Bresser et al. (68), according to the manufacturer's recommendations (Schleicher \& Schuell). Filters were hybridized as above. Similar to the RNA dot-blot data, the results were expressed as units per cell. Experiments comparing relative amounts of $\alpha 1 \mathrm{AT}$ mRNA/cell using the Quick-blot or RNA dot-blot showed no significant differences.

\section{In vitro maturation of monocytes}

Monocytes were purified as described above and cultured in RPMI-1640 with $10 \%$ FBS. The medium was changed once weekly without washing the cells. On days $1,9,11$, and 15 , after the beginning of the culture, total cellular RNA was extracted and $\alpha 1 \mathrm{AT}$ mRNA levels were quantified as described above using the amount of RNA and DNA per cell to express the data as $\alpha 1 \mathrm{AT}$ mRNA units per cell.

\section{Production and secretion of $\alpha 1 A T$ by monocytes and alveolar macrophages}

To evaluate the production and secretion of $\alpha 1 \mathrm{AT}$ by alveolar macrophages, $2 \times 10^{6}$ cells recovered by lavage were plated on plastic dishes $\left(30 \mathrm{~min} ; 37^{\circ} \mathrm{C}\right.$ ) in plating medium (methionine-free DME $+10 \%$ heatinactivated FBS previously dialyzed against $\mathrm{PBS}$ ). The cells were washed once with pulse medium (methionine-free DME $+10 \%$ dialyzed FBS) and incubated $\left(30 \mathrm{~min}, 37^{\circ} \mathrm{C}\right)$ in pulse medium with $500 \mu \mathrm{Ci} / \mathrm{ml}$ $\left[{ }^{35} \mathrm{~S}\right]$ methionine $(1,000 \mathrm{Ci} / \mathrm{mmol}$, New England Nuclear, Boston, MA) (80). In some experiments, cycloheximide $(10 \mu \mathrm{g} / \mathrm{ml})$ was added. The cells were then washed twice with PBS and then chased with medium containing an excess of methionine for $30 \mathrm{~min}, 1 \mathrm{~h}, 2$, and $3 \mathrm{~h}$ in chase medium (methionine-free DME, $10 \%$ dialyzed FBS, $6 \times 10^{-4} \mathrm{M}$ unlabeled methionine). In all studies, at the end of the chase period, the viability of the cells was $>90 \%$. At the end of each chase period, supernatants were centrifuged $(800 \mathrm{~g}, 10 \mathrm{~min})$ and the supernatants were frozen. The labeled $\alpha 1 \mathrm{AT}$ was immunoprecipitated from the supernatants using an anti- $\alpha 1 \mathrm{AT}$ antibody (Dako Corporation, Santa Barbara, CA) coated on cyanogen bromide-activated Sepharose 4B agarose (Pharmacia), prepared according to Sugiura et al. (81). The immunoprecipitation was performed in $50 \mathrm{mM}$ Tris- $\mathrm{HCl}, \mathrm{pH} 7.5,150 \mathrm{mM}$ sodium chloride, $5 \mathrm{mM}$ EDTA, $0.05 \%$ Nonidet $\mathrm{P} 40,0.01 \% \mathrm{SDS}, 1.2 \mathrm{mM}$ sodium deoxycholate, $3.0 \mathrm{mM}$ sodium azide, $1 \mathrm{mg} / \mathrm{ml}$ bovine serum albumin, $2 \mathrm{mM}$ L-methionine, and $1 \mu \mathrm{g} / \mathrm{ml} \alpha 1 \mathrm{AT}$ for $2 \mathrm{~h}, 4^{\circ} \mathrm{C}$. After incubation, the beads were layered on a discontinuous sucrose gradient $(0.5$ and $1 \mathrm{M}$ sucrose) and spun at $15,600 \mathrm{~g}, 15 \mathrm{~min}$ at $4^{\circ} \mathrm{C}$. $\alpha 1 \mathrm{AT}$ was solubilized from the beads by heating at $95^{\circ} \mathrm{C}$ for $5 \mathrm{~min}$ in $63 \mathrm{mM}$ Tris- $\mathrm{HCl}$, pH 6.8, $1 \%$ SDS, $75 \mathrm{mM}$ mercaptoethanol, and $10 \%$ glycerol. The samples were electrophoresed in a $7.5 \%$ SDS polyacrylamide gel and fluorograms were performed $(82,83)$. To ascertain the specificity of the immunoprecipitation, the same procedure was applied to beads not coated with anti- $\alpha 1 \mathrm{AT}$. Evaluation of 
purified M- and Z-type $\alpha 1 \mathrm{AT}$ standards demonstrated no quantitative differences throughout the immunoprecipitation procedure. The molecular weight was estimated by comparison with $\left[{ }^{14} \mathrm{C}\right]$-methylated protein standards, including myosin, phosphorylase B, bovine serum albumin, ovalbumin, carbonic anhydrase and lysosyme (Amersham Corp.) electrophoresed on the same gel. The autoradiographic images were quantified by densitometry. In order to rule out an amino acid pool difference at the origin of the differences observed in $\alpha 1 \mathrm{AT}$ secretion between PiMM and PiZZ mononuclear phagocytes, alveolar macrophages were labeled in similar conditions with $5 \mu \mathrm{Ci} / \mathrm{ml}$ of $\left[{ }^{14} \mathrm{C}\right]$ proline $(270 \mathrm{mCi} / \mathrm{mmol}$; Amersham Corp.), $\left[{ }^{14} \mathrm{C}\right]$ phenylalanine $(525 \mathrm{mCi} / \mathrm{mmol}$; New England Nuclear), $\left[{ }^{14} \mathrm{C}\right] l$ leucine $(317 \mathrm{mCi} / \mathrm{mmol}$; New England Nuclear), and $\left[{ }^{14} \mathrm{C}\right]$ lysine $(317 \mathrm{mCi} / \mathrm{mmol}$; New England Nuclear). Macrophages were cultured in RPMI depleted of the amino acid used for labeling (RPMI1640 Select-Amine kit; Gibco Laboratories, Grand Island, NY), and $\alpha 1 \mathrm{AT}$ was immunoprecipitated and electrophoresed as above. To further quantify the amount of $\alpha 1 \mathrm{AT}$ secreted by $Z$ and $M$ alveolar macrophages, studies were also carried out in which PiMM and PiZZ alveolar macrophages were labeled with $\left[{ }^{35}\right.$ S]methionine for $24 \mathrm{~h}(80)$ and the amount of labeled $\alpha 1 \mathrm{AT}$ secreted by the macrophages was quantified as described above.

\section{Statistical analysis}

All comparisons between groups were made using the two-tailed Student's $t$ test.

\section{Results}

Expression of the $\alpha 1 A T$ gene by liver and mononuclear phagocytes. Evaluation of the RNA populations of normal blood monocytes and alveolar macrophages as well as the mononuclear phagocyte cell line U-937 convincingly demonstrated that mononuclear phagocytes, like hepatocytes, express the $\alpha 1 \mathrm{AT}$ gene (Fig. 1). Northern blot analysis of RNA obtained from normal human liver showed that the $\alpha 1 \mathrm{AT}$ gene is expressed in human liver as a single mRNA of $1.75 \mathrm{~kb}$. Consistent with this observation, both hepatoma (SK-HEP-1) and fetal liver (CLCL) cell lines also expressed the $\alpha 1 \mathrm{AT}$ gene as a $1.75-\mathrm{kb}$ mRNA. Similarly, cellular RNA extracted from normal alveolar macrophages, normal monocytes, and, to a lesser extent, the monocyte-like cell line U-937, demonstrated the same mRNA species. The $\alpha 1 \mathrm{AT}$ gene was also expressed in normal PiMM blood neutrophils (Fig. $1 A$ ) as well as in PiZZ neutrophils (not shown). However, $\alpha 1$ AT mRNA was not detected in normal blood lymphocytes, nor in the human lung fibroblast strain HFL-1 (Fig. $1 A$ ). However, when the same RNA samples were hybridized with a $\gamma$-actin cDNA, the expected $2.0-\mathrm{kb}$ mRNA was observed in all samples, including lymphocytes and fibroblasts, cells that did not express the $\alpha 1 \mathrm{AT}$ gene (Fig. $1 \mathrm{~B}$ ). In all cases where hybridization was observed with the $\alpha 1 \mathrm{AT}$ cDNA and/or $\gamma$ actin cDNA, no hybridization was seen with plasmid pBR322 without the insert.

Relative quantification of the expression of the $\alpha 1 A T$ gene by mononuclear phagocytes. Although mononuclear phagocytes express the $\alpha 1 \mathrm{AT}$ gene, their level of expression is lower than that observed in the liver (Fig. 2). Dot-blot hybridization analysis demonstrated that the amount of $\alpha 1 \mathrm{AT}$ mRNA per cell for liver was 200 -fold greater than that for blood monocytes collected

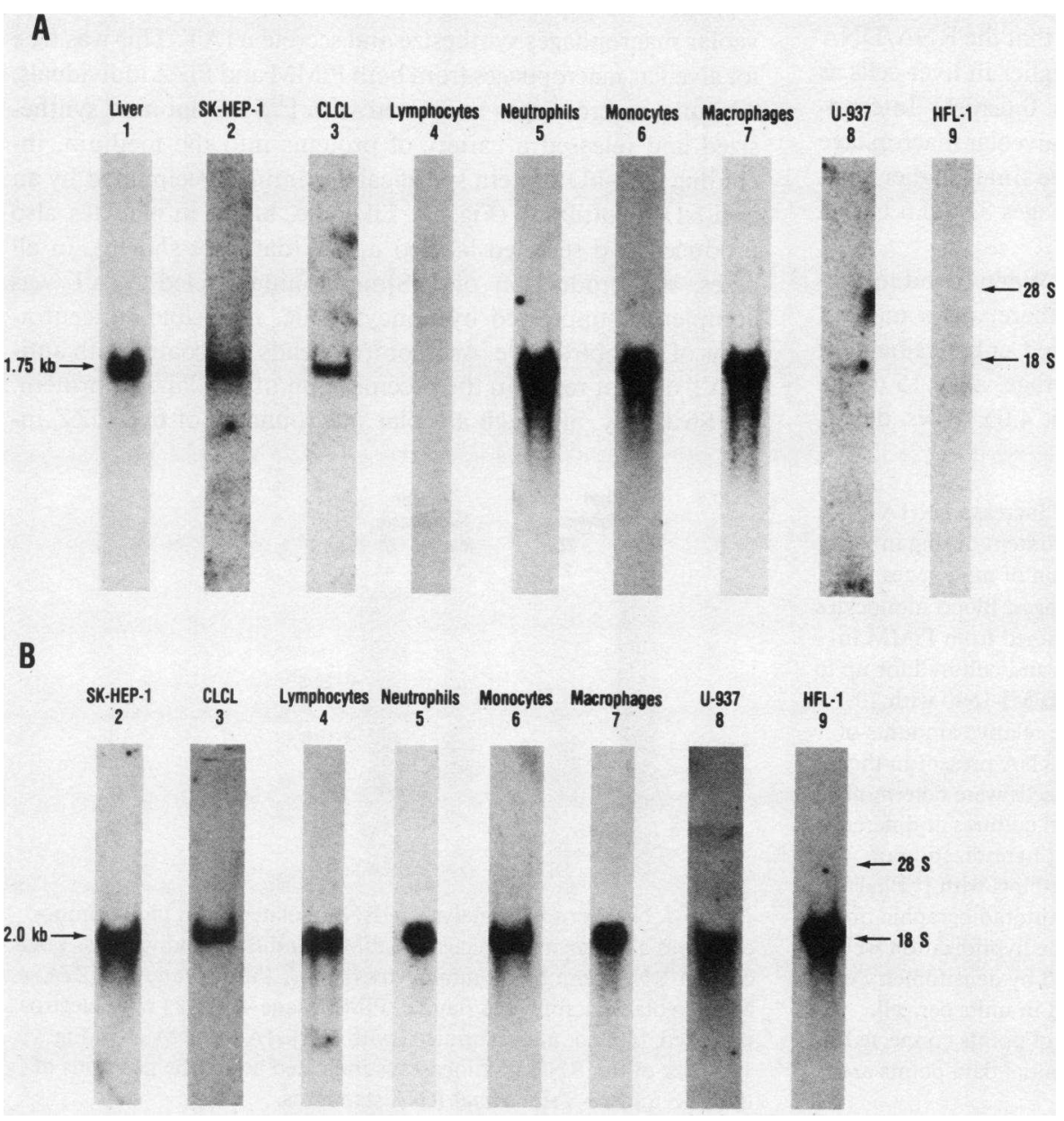

Figure 1. Identification of $\alpha 1 \mathrm{AT}$ mRNA in various cell types. Shown is a Northern blot analysis of RNA isolated from various sources and hybridized to $(A)\left[{ }^{32} \mathrm{P}\right] \alpha 1 \mathrm{AT}$ cDNA and $(B)$ $\left[{ }^{32} \mathrm{P}\right] \gamma$-actin cDNA. Total cellular RNA was electrophoresed in $1 \%$ agarose gels in denaturing conditions, blotted to nitrocellulose, and hybridized. In both panels the source of the RNA in each of the lanes is as follows: (1) liver; (2) SK-HEP-1; (3) CLCL; (4) lymphocytes; (5) neutrophils; (6) monocytes; (7) alveolar macrophages; (8) U-937; and (9) HFL-1. Size of the RNA in kilobases (kb) is noted as are the positions of the 18-S and 28-S ribosomal RNA. The amount of RNA $(5 \mu \mathrm{g})$ is the same in all lanes both panels. The lymphocytes, neutrophils, monocytes, and alveolar macrophages were all obtained from individuals with $\alpha$ IAT phenotype PiMM. 


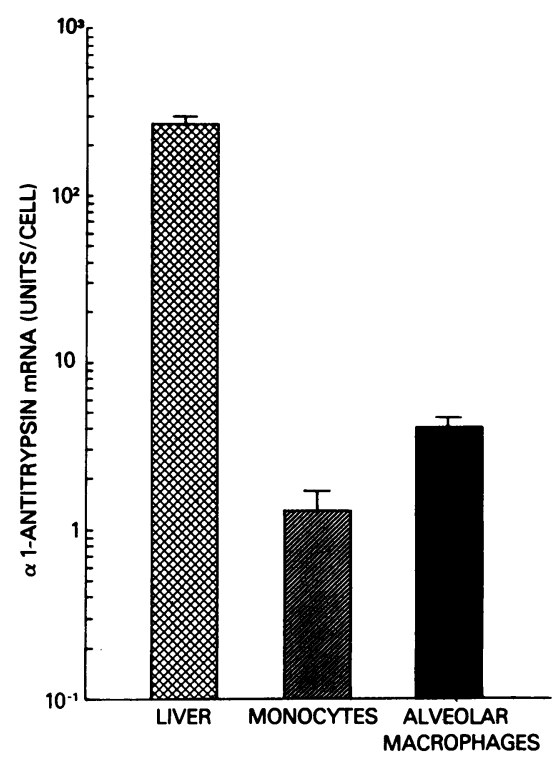

Figure 2. Comparison of the relative amounts of $\alpha 1 \mathrm{AT}$ mRNA present in the liver, blood monocytes (collected after $1 \mathrm{~h}$ of adherence), and alveolar macrophages of PiMM individuals. mRNA contents were determined after hybridization of RNA dot-blots with $\left[{ }^{32} \mathrm{P}\right] \alpha 1 \mathrm{AT}$ cDNA. Autoradiographic images of the hybridization were quantified by densitometry and expressed in units per cell after measurement of the RNA/DNA ratio in the samples.

$1 \mathrm{~h}$ after plating of blood mononuclear cells $(275 \pm 25 \mathrm{U} /$ cell vs. $1.3 \pm 0.4 \mathrm{U} /$ cell). This difference was not simply related to an increase of total cellular RNA in the liver in that the RNA/DNA ratio for hepatocytes was only four times higher in liver cells as compared to blood monocytes $(2.4 \pm 0.4$ vs. $0.6 \pm 0.1)$. Interestingly, although the $\alpha 1 \mathrm{AT}$ mRNA content of alveolar macrophage was 70-fold less than liver cells, it was three times higher than that of blood monocytes (alveolar macrophages $3.9 \pm 0.6 \mathrm{U} /$ cell vs. $1.3 \pm 0.4 \mathrm{U} /$ cell, $P<0.05)$.

In vitro maturation of blood monocytes. When blood monocytes were cultured in vitro for 11-15 d, there was a marked increase in total cellular RNA and a marked enhancement of $\alpha 1$ AT gene expression (Fig. 3). On the average, after $15 \mathrm{~d}$, the RNA/DNA ratio increased 14-fold (day 15, $4.0 \pm 1.6$ vs. day 1,

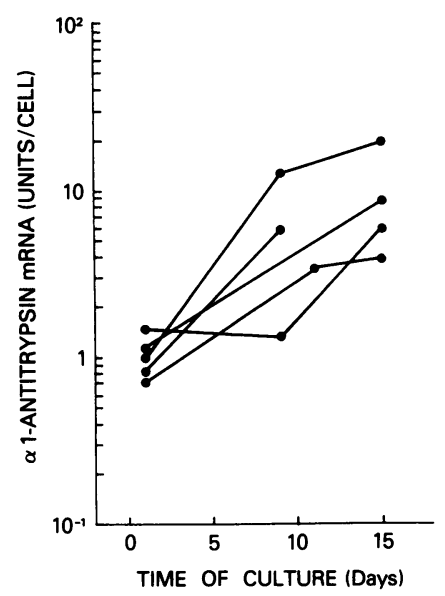

Figure 3. Increase in $\alpha 1 \mathrm{AT}$ mRNA content during in vitro maturation of monocytes to macrophages. Blood monocytes were obtained from PiMM individuals and cultured for up to $15 \mathrm{~d}$ in RPMI- 1640 with $10 \%$ FBS. The relative amounts of $\alpha 1 \mathrm{AT}$ mRNA present in the cultured cells were determined in parallel cultures at different days after hybridization of RNA dot-blots with $\left[{ }^{32} \mathrm{P}\right] \alpha 1 \mathrm{AT}$ cDNA. Autoradiographic images of the hybridization were quantified by densitometry and expressed in units per cell. Each set of points connected by lines represents separate series of cultures. The initial data points are after $1 \mathrm{~d}$ in culture.
$0.28 \pm 0.24$ ) and, despite the slight decrease of the $\alpha 1 \mathrm{AT}$ mRNA/ total RNA ratio during in vitro maturation, the marked increase in total cellular RNA led to an $\alpha 1 \mathrm{AT}$ mRNA level increase of 10-fold over the same period of culture (day 15, 9.8 $\pm 3.1 \mathrm{U} /$ cell vs. day $1,1.0 \pm 0.1 \mathrm{U} /$ cell). In comparison, the total cellular RNA/ DNA ratio of freshly isolated alveolar macrophages was $1.4 \pm 0.5$. Together, these in vitro observations are consistent with the observations that the $\alpha 1 \mathrm{AT}$ mRNA of freshly obtained alveolar macrophages are severalfold greater than that of blood monocytes.

Expression of the $\alpha 1 A T$ gene in mononuclear phagocytes of PiZZ individuals. Despite the fact that PiZZ individuals have low $\alpha 1 \mathrm{AT}$ serum levels, mononuclear phagocytes from PiZZ patients express the $\alpha 1 \mathrm{AT}$ gene (Fig. 4). Furthermore, in both monocytes and alveolar macrophages, the level of $\alpha$ AT gene expression was similar in PiZZ and PiMM individuals (Fig. 5). Northern blot analysis of total cellular RNA revealed the presence of a similar species of $\alpha 1 \mathrm{AT}$ mRNA in both monocytes and alveolar macrophages of PiZZ individuals as that of PiMM individuals; in both, the size was $1.75 \mathrm{~kb}$ (Fig. 4). Likewise, quantitative comparison of the mRNA levels showed no significant difference in the amount of $\alpha 1 \mathrm{AT}$ mRNA expressed in mononuclear phagocytes between PiZZ and PiMM individuals. This was true for both monocytes (PiMM 0.8 $\pm 0.2 \mathrm{U} /$ cell vs. PiZZ 1.3 $\pm 0.4 \mathrm{U} /$ cell, $P>0.5$ ) and alveolar macrophages (PiMM $4.4 \pm 0.4 \mathrm{U} /$ cell vs. PiZZ 3.9 $\pm 0.6 \mathrm{U} /$ cell, $P>0.5$ ) (Fig. 5). Thus, PiZZ mononuclear phagocytes express the $\alpha 1 \mathrm{AT}$ gene in a fashion similar to that of PiMM mononuclear phagocytes.

De novo production and synthesis of $\alpha 1 A T$ by alveolar macrophages. As expected for cells expressing the $\alpha 1 \mathrm{AT}$ gene, alveolar macrophages synthesize and secrete $\alpha 1 \mathrm{AT}$. This was true for alveolar macrophages from both PiMM and PiZZ individuals. Alveolar macrophages incubated with $\left[{ }^{35}\right.$ S $]$ methionine synthesized and released a variety of proteins into the medium, including a $52-\mathrm{kD}$ protein specifically immunoprecipitated by an anti- $\alpha$ 1AT antibody (Fig. 6). Likewise, blood monocytes also produced and secreted labeled $\alpha 1 \mathrm{AT}$ (data not shown). In all cases, the production of $\left[{ }^{35} \mathrm{~S}\right]$ methionine-labeled $\alpha 1 \mathrm{AT}$ was completely suppressed by noncytotoxic, reversible concentrations of cycloheximide. As a control, beads not coated with anti$\alpha 1 \mathrm{AT}$ did not result in the precipitation of any labeled protein.

Strikingly, although alveolar macrophages of five PiZZ in-

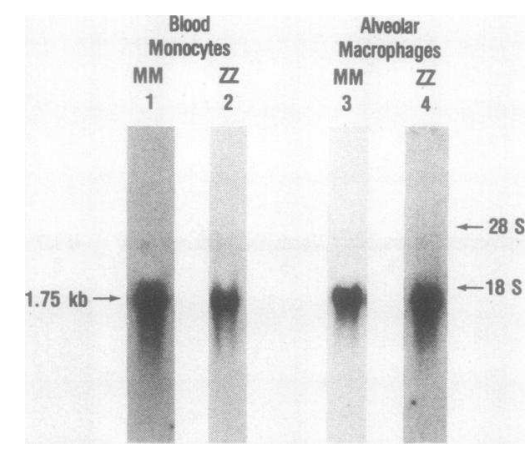

Figure 4. Northern blot analysis of RNA isolated from blood monocytes and alveolar macrophages of PiMM and PiZZ individuals. Total cellular RNA from blood monocytes (lane 1, PiMM; lane 2, PiZZ) and alveolar macrophages (lane 3, PiMM; lane 4, PiZZ) were electrophoresed, blotted, and hybridized with $\left[{ }^{32} \mathrm{P}\right] \alpha 1 \mathrm{AT}$ cDNA as in Fig. $1 \mathrm{~A}$. Size of the RNA in kilobases is indicated as are the positions of the 18-S and 28-S ribosomal RNA standards. 


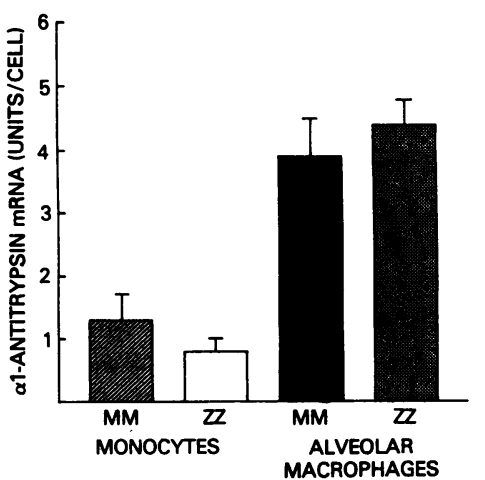

dividuals also synthesized and secreted $\alpha 1 \mathrm{AT}$, after a 30 -min "pulse" with $\left[{ }^{35} \mathrm{~S}\right]$ methionine, at each time point of a $30-\mathrm{min}$ to 3-h chase period, the amount secreted per cell was markedly less than that for PiMM alveolar macrophages of three normal individuals (Fig. 6). Controls of de novo synthesis by alveolar macrophages of proteins other than $\alpha 1 \mathrm{AT}$ were done by examining the release of fibronectin and antichymotrypsin in the same supernatants. The different $\mathrm{Pi}$ phenotypes were not associated with any difference in the release of these control proteins. Furthermore, when the cells were labeled for $24 \mathrm{~h}$, scanning of the autoradiogram of the secreted $\alpha 1 \mathrm{AT}$ demonstrated that PiZZ alveolar macrophages secreted 10-fold less $\alpha 1$ AT than PiMM alveolar macrophages (Fig. 7; PiMM 89 21 U/cell per 24 h vs. PiZZ 6.3 $\pm 2.1 \mathrm{U} /$ cell per $24 \mathrm{~h} ; P<0.05)$. Quantitation of the secretion of $\left[{ }^{14} \mathrm{C}\right]$-labeled $\alpha 1 \mathrm{AT}$ (with leucine, lysine, proline, and phenylalanine) showed the same difference between PiMM and PiZZ macrophages (data not shown).

\section{Discussion}

In addition to the liver, mononuclear phagocytes, including blood monocytes and alveolar macrophages, express the $\alpha 1 \mathrm{AT}$ gene. Analysis of mononuclear phagocytes of individuals with

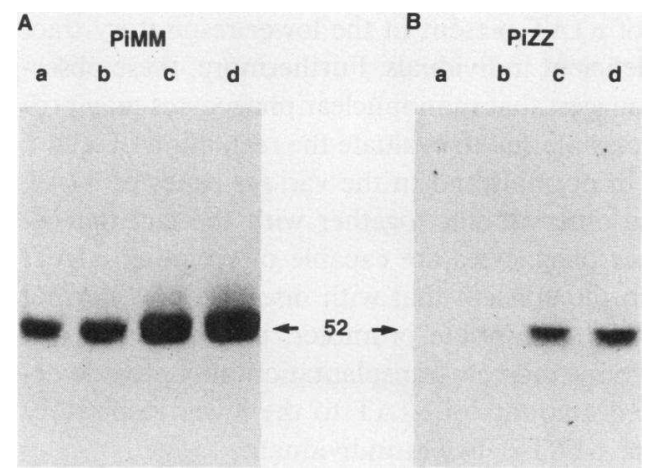

Figure 6. Evaluation of $\alpha 1 \mathrm{AT}$ secretion by alveolar macrophages of PiMM and PiZZ individuals. Alveolar macrophages were pulsed for 30 min with $\left[{ }^{35} S\right]$ methionine and chased in medium with cold methionine for various time periods. The supernatants were immunoprecipitated with an anti- $\alpha 1 \mathrm{AT}$ antibody and evaluated by electrophoresis on SDS $7.5 \%$ polyacrylamide gels. Autoradiograms were exposed for $4 \mathrm{~d}$. (A) PiMM alveolar macrophages. Lane $a, 30$-min chase; $b, 1 \mathrm{~h} ; c, 2 \mathrm{~h}$; $d, 3$ h. (B) PiZZ alveolar macrophages. Lane $a, 30$-min chase; $b, 1 \mathrm{~h}$; $c, 2 \mathrm{~h} ; d, 3 \mathrm{~h}$.

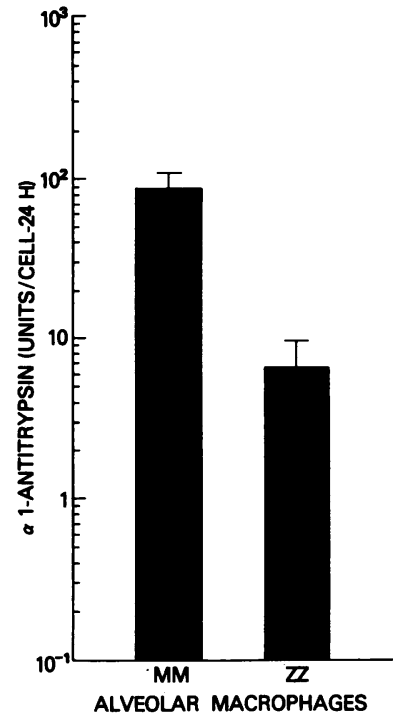

the normal (MM) $\alpha 1 \mathrm{AT}$ phenotype using a full-length cDNA probe for $\alpha 1 \mathrm{AT}$ demonstrated that monocytes and alveolar macrophages spontaneously express a single $\alpha 1 \mathrm{AT}$ mRNA of $1.75 \mathrm{~kb}$, identical to that of liver. Because $\alpha 1 \mathrm{AT}$ mRNA was identical for liver and mononuclear phagocytes, $\alpha 1 \mathrm{AT}$ mRNA expression can be assessed both in liver tissue samples and mononuclear phagocytes, despite differences in tissue origin. Relative quantitation of the mRNA levels demonstrated that monocyte $\alpha 1 \mathrm{AT}$ mRNA levels were 200 -fold less than liver and that alveolar macrophage $\alpha 1 \mathrm{AT}$ mRNA levels were 70 -fold less than liver, suggesting that, on a per cell basis, mononuclear phagocytes express less $\alpha$ 1AT transcript than liver but that, in the process of maturation from monocytes, alveolar macrophages up-regulate $\alpha 1 \mathrm{AT}$ gene expression. Consistent with this observation, an in vitro model of monocyte to macrophage maturation demonstrated 10-fold augmentation of average $\alpha 1 \mathrm{AT}$ mRNA levels per cell. Importantly, analysis of alveolar macrophages of individuals with PiZZ-type $\alpha 1 \mathrm{AT}$ deficiency demonstrated that, although the $\alpha 1 \mathrm{AT}$ mRNA levels were similar to that of alveolar macrophages of normal PiMM individuals, the PiZZ macrophages synthesized and secreted 10 -fold less $\alpha 1 \mathrm{AT}$, consistent with the knowledge that the consequences of the $\alpha 1 \mathrm{AT} \mathrm{Z}$-gene abnormality (M: glu ${ }^{342}$ to $\mathrm{Z}$ : lys $^{342}$, GAG to AAG in exon $\mathrm{V}$ ) is expressed in mononuclear phagocytes as well as in the liver and that appearance of the radiolabeled $\alpha 1 \mathrm{AT}$ in supernatants is parallel to its disappearance from the cell lysate $(27,46)$. Although the total mass of $\alpha 1 \mathrm{AT}$ produced by mononuclear phagocytes is probably far less than the total mass produced by the liver, the fact that alveolar macrophages reside directly at the site where $\alpha 1$ AT functions to inhibit neutrophil elastase suggests that alveolar macrophages may play a role in the $\alpha 1 \mathrm{AT}-$ neutrophil elastase balance in the lower respiratory tract in both normals and in $\alpha 1 \mathrm{AT}$ deficiency.

$\alpha 1 A T$ gene expression by mononuclear phagocytes. Monocytes and alveolar macrophages from normal (PiMM) individuals express a mRNA transcript, as does the mononuclear cell line U-937. Furthermore, alveolar macrophages of PiMM individuals spontaneously synthesize and secrete $\alpha 1 \mathrm{AT}$. Comparison of the mononuclear phagocyte $\alpha 1 \mathrm{AT}$ mRNA with $\alpha 1 \mathrm{AT}$ mRNA of human liver, the hepatoma cell line SK-HEP-1, and the fetal liver cell line CLCL demonstrated that all express a single $\alpha 1 \mathrm{AT}$ 
mRNA transcript of $1.75 \mathrm{~kb}$. Together these observations suggest that mononuclear phagocytes, including mononuclear phagocytes recovered from the lower respiratory tract, normally express an $\alpha$ 1AT gene in a fashion qualitatively similar to that of normal human liver. However, comparison of the quantities of $\alpha 1 \mathrm{AT}$ mRNA levels in liver, monocytes, and alveolar macrophages showed that, on an average per cell basis, the expression of an $\alpha 1$ AT mRNA transcript by blood monocytes is 200 -fold less than that of liver whereas that of alveolar macrophages is 70 fold less than liver. Thus, while mononuclear phagocytes clearly express the $\alpha 1 \mathrm{AT}$ gene, they do so less efficiently than do liver cells.

These observations are consistent with the observations of others who have found that human alveolar macrophages contain $\alpha 1 \mathrm{AT}(37-40)$, and that rat alveolar macrophages synthesize $\alpha 1 \mathrm{AT}$ (41) as do normal human blood monocytes (27, 42-44, 46). Furthermore, Budek et al. (45) have shown that when rat lung mRNA is translated in vitro in a rabbit reticulocyte system, $\alpha 1 \mathrm{AT}$ is produced, and Perlmutter et al. $(27,46)$ have recently demonstrated $\alpha 1 \mathrm{AT}$ mRNA transcripts in normal human monocytes, alveolar macrophages, and breast milk macrophages with characteristics similar to those that we observed. In addition, the studies of Isaacson et al. (40) showing that liver, spleen, and lymph node macrophages all contain $\alpha 1 \mathrm{AT}$ are consonant with the concept that all mononuclear phagocytes express the $\alpha 1 \mathrm{AT}$ gene.

In addition to mononuclear phagocytes, we noted that neutrophils expressed an $\alpha 1$ AT mRNA transcript, whereas, in contrast, blood lymphocytes and lung fibroblasts did not. These observations are consistent with the finding by Andersen (43, 44) that neutrophils produce $\alpha 1 \mathrm{AT}$ and the findings of others that noted lymphocytes and fibroblasts do not $(40,42)$. Furthermore, the observation of Rogers et al. (28) that unfractionated blood leukocytes express $\alpha 1 \mathrm{AT}$ mRNA, but less than the liver, is consistent with the concept that not only do blood monocytes express $\alpha 1 \mathrm{AT}$ but that neutrophils do as well.

Modulation of $\alpha 1 A T$ gene expression during mononuclear phagocyte maturation. Consistent with the observation that alveolar macrophages recovered from the lungs of normal individuals contain threefold more $\alpha 1 \mathrm{AT}$ mRNA than autologous blood monocytes, in vitro studies demonstrated that when blood monocytes are allowed to "mature" into macrophages in culture, these cells (on a per cell average) contain severalfold more copies of $\alpha 1$ AT mRNA than the original blood monocytes. This increase is related to a nonspecific augmentation of total cellular RNA per cell during in vitro maturation. The observation that these $\alpha 1 \mathrm{AT}$-producing cells can modulate the expression of the $\alpha$ IAT gene is consistent with the knowledge that liver cells can modulate $\alpha 1 \mathrm{AT}$ gene expression both in vivo $(17,84)$ and in vitro (18), and that $\alpha 1 \mathrm{AT}$ plasma levels can be up-regulated in humans, such as that occurs in inflammatory states and with the effect of steroid sex hormones (84-91). Our observations appear to be inconsistent with that of Perlmutter et al. (46), who found a decrease in $\alpha 1 \mathrm{AT}$ mRNA during in vitro maturation of monocytes. The reasons for this discrepancy are not clear, but may be related to the fact that we expressed our data on an average per cell basis after accounting for the RNA/DNA ratios in monocytes whereas Perlmutter et al. (46) expressed their data on the basis of RNA. In this context, when our data are evaluated on the basis of RNA without considering the number of cells used from which the RNA was derived, these observations are similar to the data of Perlmutter et al. (46).
The concept that mononuclear phagocytes modulate the expression of various genes during the maturation process is consistent with the knowledge that the array of proteins produced by tissue macrophages is both qualitatively and quantitatively different from that of blood monocytes. Included among such proteins are the complement proteins $(79,92,93)$, the transferrin receptor (94-96), fibronectin (97), interleukin 1 (97), histocompatibility antigens (98), and a growth factor (99).

$\alpha 1 A T$ gene expression by mononuclear phagocytes in PiZZ $\alpha 1 A T$ deficiency. The pathogenesis of the decreased plasma levels of $\alpha 1 \mathrm{AT}$ in PiZZ individuals is now understood to result from the glu $^{342}$ to lys $^{342}$ substitution, likely to cause a slow rate of folding of the newly synthesized $\alpha 1 \mathrm{AT}$ in the RER, allowing the $\alpha 1 \mathrm{AT}$ with its incompletely trimmed carbohydrate side chains to aggregate and precipitate in the RER, and thus not be normally translocated to the Golgi complex and subsequently secreted (4, 35). Our observations that alveolar macrophages of PiZZ $\alpha 1 \mathrm{AT}$ deficient individuals have normal levels of $\alpha 1 \mathrm{AT}$ mRNA yet secrete less $\alpha 1 \mathrm{AT}$ are completely consistent with these concepts. It is also completely consistent with the observations that when equal amounts of $\mathrm{M}$ and $\mathrm{Z} \alpha 1 \mathrm{AT}$ mRNA obtained from liver are injected into Xenopus oocytes, the Z-type $\alpha 1 \mathrm{AT}$ mRNA results in the secretion of less than normal amounts of $\alpha 1 \mathrm{AT}$ (26, 27). It is also consistent with the observations of Errington et al. (33) that PiZZ liver translates as efficiently as does PiMM liver mRNA in a wheat germ system and the observations of Bathurst et al. (25) and Sharp et al. (personal communication) that $\mathrm{M}$ and $\mathrm{Z}$ liver contains the same relative amount of $\alpha 1 \mathrm{AT}$ mRNA. The decreased secretion of labeled $\alpha 1$ AT by PiZZ macrophages is consistent with similar results obtained with blood monocytes $(27,42)$ and liver $(34)$. Together, these observations suggest that the $M$ to $Z$ substitution of codon AAG for GAG has no effect on the amount of mRNA transcript present in $\alpha 1$ AT-producing cells. Thus, the concept that a relatively high level of $\alpha 1 \mathrm{AT}$ in the extracellular milieu might down-regulate (and thus low levels presumably up-regulate) $\alpha 1 \mathrm{AT}$ mRNA levels (18) likely does not occur in vivo.

Most importantly, the results of the present study, as well as that of Perlmutter et al. $(27,46)$, suggest that mononuclear phagocytes contribute to the adequate levels of $\alpha 1 \mathrm{AT}$ present in the lower respiratory tract of normal individuals and the insufficient levels of $\alpha 1 \mathrm{AT}$ present in the lower respiratory tract of PiZZ $\alpha 1$ AT-deficient individuals. Furthermore, these observations strongly suggest that mononuclear phagocytes may provide a readily accessible cell to evaluate the regulation of $\alpha 1 \mathrm{AT}$ gene expression in normals and in the various states of $\alpha 1 \mathrm{AT}$ deficiency. These observations, together with the fact that Ztype mononuclear phagocytes are capable of secreting $\alpha 1 \mathrm{AT}$, lends credence to the concept that with insertion of a normal $\alpha 1 \mathrm{AT}$ gene and an appropriate promoter, into bone marrow cells, autologous bone marrow transplantation may provide delivery of increased amounts of $\alpha 1 \mathrm{AT}$ to the lower respiratory tract of PiZZ-type $\alpha 1$ AT-deficient individuals.

\section{Acknowledgments}

We would like to thank Dr. M. Wewers for his help in carrying out this project, and Dr. L. Kedes and P. Gunning for providing us with the $\boldsymbol{\gamma}$ actin cDNA.

J. F. Mornex was supported, in part, by a Lilly International Fellowship. 


\section{References}

1. Kueppers, F., and L. F. Black. 1974. Alpha 1-antitrypsin and its deficiency. Am. Rev. Respir. Dis. 110:176-194.

2. Fagerhol, M. K., and D. W. Cox. 1981. The Pi polymorphism: genetic, biochemical, and clinical aspects of human $\alpha 1$-antitrypsin. $A d v$. Hum. Genet. 11:1-62.

3. Gadek, J. E., and R. G. Crystal. 1982. $\alpha 1$-antitrypsin deficiency. In The Metabolic Basis of Inherited Disease. J. B. Stanbury, J. B. Wyngaarden, D. S. Fredrickson, J. L. Goldstein, and M. S. Brown, editors. McGraw-Hill Book Co., New York. 1450-1467.

4. Carrell, R. W., J. O. Jeppsson, C. B. Laurell, S. O. Brennan, M. C. Owen, L. Vaughan, and D. R. Boswell. 1982. Structure and variation of human $\alpha 1$-antitrypsin. Nature (Lond.). 298:329-334.

5. Travis, J., and G. S. Salvesen. 1983. Human plasma proteinase inhibitors. Annu. Rev. Biochem. 52:655-709.

6. Eriksson, S. 1964. Pulmonary emphysema and alphal-antitrypsin deficiency. Acta Med. Scand. 175:197-205.

7. Morse, J. O. 1978. Alpha 1-antitrypsin deficiency. N. Engl. J. Med. 299:1045-1048; 1099-1105.

8. Gadek, J. E., G. A. Fells, R. L. Zimmerman, S. I. Rennard, and R. G. Crystal. 1981. Antielastases of the human alveolar structures: implications for the protease-antiprotease theory of emphysema. J. Clin. Invest. 68:889-898.

9. Stone, P. J. 1983. The elastase-antielastase hypothesis of the pathogenesis of emphysema. Clin. Chest Med. 4:405-412.

10. Mornex, J. F., and R. G. Crystal. 1984. Protease-antiprotease imbalance in lung disease. In Marker Proteins in Inflammation. Vol. 2. P. Arnaud, J. Bienvenu, and P. Laurent, editors, Walter de Gruyter, Berlin. 261-270.

11. Leicht, M., G. L. Long, T. Chandra, K. Kurachi, V. J. Kidd, M. Mace, E. W. Davie, and S. L. Woo. 1982. Sequence homology and structural comparison between the chromosomal human $\alpha 1$-antitrypsin and chicken ovalbumin. Nature (Lond.). 297:655-659.

12. Kidd, V. J., R. B. Wallace, K. Itakura, and S. L. Woo. 1983. $\alpha 1$ antitrypsin deficiency detection by direct analysis of the mutation in the gene. Nature (Lond.). 304:230-234.

13. Darlington, G. J., K. H. Astrin, S. P. Muirhead, R. J. Desnick, and M. Smith. 1982. Assignment of human $\alpha 1$-antitrypsin to chromosome 14 by somatic cell hybrid analysis. Proc. Natl. Acad. Sci. USA. 79: 870-873.

14. Cox, D. W., A. M. Johnson, and M. K. Fagerhol. 1980. Report of nomenclature meeting for alpha 1-antitrypsin, INSERM, Rouen/BoisGuillaume-1978. Hum. Genet. 53:429-433.

15. Yoshida, A., J. Lieberman, L. Gaidulis, and C. Ewing. 1976. Molecular abnormality of human alphal-antitrypsin variant (Pi-ZZ) associated with plasma activity deficiency. Proc. Natl. Acad. Sci. USA. 73: 1324-1328.

16. Hercz, A., and N. Harpaz. 1980. Characterization of the oligosaccharides of liver $\mathrm{Z}$ variant $\alpha 1$-antitrypsin. Can. J. Biochem. 58:644648.

17. Koj, A., E. Regoeczi, C. J. Toews, R. Leveille, and J. Gauldie. 1978. Synthesis of antithrombin III and alpha-1-antitrypsin by perfused rat liver. Biochim. Biophys. Acta. 539:496-504.

18. Eriksson, S., A. Ragnar, and B. Astedt. 1978. Organ cultures of human fetal hepatocytes in the study of extra- and intracellular $\alpha 1$ antitrypsin. Biochim. Biophys. Acta. 542:496-505.

19. Turner, B. M., and V.S. Turner. 1980. Secretion of $\alpha 1$-antitrypsin by an established human hepatoma cell line and by human/mouse hybrids. Somatic Cell Genet. 6:1-14.

20. Glasgow, J. E., A. Bagdasarian, and R. W. Colman. 1982. Functional alphal protease inhibitor produced by a human hepatoma cell line. J. Lab. Clin: Med. 99:108-117.

21. Gautier, M., J. P. Martin, and G. Polini. 1977. In vitro synthesis of alpha-1-antitrypsin in long term monolayer human liver cell cultures. Biomedicine. 27:116-119.

22. Geiger, T., W. Northemann, E. Schmelzer, V. Gross, F. Gauthier, and P. C. Heinrich. 1982. Synthesis of $\alpha 1$-antitrypsin in rat-liver hepatocytes and in a cell-free system. Eur. J. Biochem. 126:189-195.

23. Carlson, J., and J. Stenflo. 1981. Rat $\alpha 1$-antitrypsin. Preliminary characterisation of the in vitro mRNA translation product. FEBS (Fed. Eur. Biochem. Soc.) Lett. 130:297-300.

24. Vercaigne, D., J. Bourguignon, F. Lefebvre, and J. P. Martin. 1982. Identification of the translation products of $\alpha$-1-antitrypsin mRNA from baboon liver polysomes. FEBS (Fed. Eur. Biochem. Soc.) Lett. 137:231-235.

25. Bathurst, I. C., J. Stenflo, D. M. Errington, and R. W. Carrell. 1983. Translation and processing of normal (PiMM) and abnormal PiZZ human $\alpha 1$-antitrypsin. FEBS (Fed. Eur. Biochem. Soc.) Lett. 153:270274.

26. Foreman, R. C., J. D. Judah, and A. Colman. 1984. Xenopus oocytes can synthesise but do not secrete the $Z$ variant of human $\alpha 1$ antitrypsin. FEBS (Fed. Eur. Biochem. Soc.) Lett. 168:84-88.

27. Perlmutter, D. H., R. M. Kay, F. S. Cole, T. H. Rossing, D. van Thiel, and H. R. Colten. 1985. The cellular defect in $\alpha 1$-proteinase inhibitor $(\alpha 1-\mathrm{Pi})$ deficiency is expressed in human monocytes and in Xenopus oocytes injected with human liver mRNA. Proc. Natl. Acad. Sci. USA. 82:6918-6921.

28. Rogers, J., N. Kalsheker, S. Wallis, A. Speer, C. H. Coutelle, D. Woods, and S. E. Humphries. 1983. The isolation of a clone for human $\alpha 1$-antitrypsin and the detection of $\alpha 1$-antitrypsin in mRNA from liver and leukocytes. Biochem. Biophys. Res. Commun. 116:375-382.

29. Bollen, A., R. Loriau, A. Herzog, and P. Herion. 1984. Expression of human $\alpha 1$-antitrypsin in Escherichia coli. FEBS (Fed. Eur. Biochem. Soc.) Lett. 166:67-70.

30. Long, G. L., T. Chandra, S. L. Woo, E. W. Davie, and K. Kurachi. 1984. Complete sequence of the cDNA for human $\alpha 1$-antitrypsin and the gene for the S variant. Biochemistry. 23:4828-4837.

31. Courtney, M., A. Buchwalder, L. H. Tessier, M. Jaye, A. Benavente, A. Balland, V. Kohli, R. Lathe, P. Tolstoshev, and J. P. Lecocq. 1984. High-level expression of biologically active human $\alpha 1$-antitrypsin in E. coli. Proc. Natl. Acad. Sci. USA. 81:669-673.

32. Berger, F. G., and H. Baumann. 1985. An evolutionary switch in tissue-specific gene expression: abundant expression of $\alpha 1$-antitrypsin in the kidney of a wild mouse species. J. Biol. Chem. 260:1160-1165.

33. Errington, D. M., I. C. Bathurst, E. D. Janus, and R. W. Carrell. 1982. In vitro synthesis of $M$ and $Z$ forms of human $\alpha 1$-antitrypsin. FEBS (Fed. Eur. Biochem. Soc.) Lett. 148:83-86.

34. Bhan, A. K., R. J. Grand, H. R. Colten, and C. A. Alper. 1976. Liver in $\alpha 1$-antitrypsin deficiency: morphologic observations and in vitro synthesis of $\alpha 1$-antitrypsin. Pediatr. Res. 10:35-40.

35. Loebermann, H., R. Tokuoka, J. Deisenhofer, and R. Huber. 1984. Human $\alpha 1$-proteinase inhibitor: crystal structure analysis of two crystal modifications, molecular model and preliminary analysis of the implications for function. J. Mol. Biol. 177:531-556.

36. Yoshida, A., and T. Mega. 1979. Carbohydrate composition of normal and variant human alpha 1-protease inhibitors. Arch. Biochem. Biophys. 195:591-595.

37. Cohen, A. B. 1973. Interrelationships between the human alveolar macrophage and alpha-1-antitrypsin. J. Clin. Invest. 53:2793-2799.

38. Olsen, G. N., J. O. Harris, J. R. Castle, R. H. Waldman, and H. J. Karmgard. 1975. Alpha-1-antitrypsin content in the serum, alveolar macrophages, and alveolar lavage fluid of smoking and nonsmoking normal subjects. J. Clin. Invest. 55:427-430.

39. Gupta, P. K., J. K. Frost, S. Geddes, B. Aracil, and F. Davidovski. 1979. Morphological identification of alpha-1-antitrypsin in pulmonary macrophages. Hum. Pathol. 10:345-347.

40. Isaacson, P., D. B. Jones, G. H. Milward-Sadler, M. A. Judd, and S. Payne. 1981. Alpha-1-antitrypsin in human macrophages. J. Clin. Pathol. 34:982-990.

41. White, R., D. Lee, G. S. Habicht, and A. Janoff. 1981. Secretion of alpha 1-protease inhibitor by cultured rat alveolar macrophages. Am. Rev. Respir. Dis. 123:447-449.

42. van Furth, R., J. A. Kramps, and M. M. Diesselhof-den Dulk. 
1983. Synthesis of alpha-1-antitrypsin by human monocytes. Clin. Exp. Immunol. 51:551-557.

43. Andersen, M. M. 1983. Leucocyte-associated plasma proteins. Scand. J. Clin. Lab. Invest. 43:49-59.

44. Andersen, M. M. 1984. Leucocyte-associated plasma proteins in leucocytes during disease states, and in leukaemic cells. Scand. J. Clin. Lab. Invest. 44:257-265.

45. Budek, W., P. Bunning, and P. C. Heinrich. 1984. Rat lung tissue is a site of $\alpha 1$-proteinase inhibitor synthesis: evidence by cell-free translation. Biochem. Biophys. Res. Commun. 122:394-400.

46. Perlmutter, D. H., F. S. Cole, P. Kilbridge, T. H. Rossing, and H. R. Colten. 1985. Expression of the $\alpha 1$-proteinase inhibitor gene in human monocytes and macrophages. Proc. Natl. Acad. Sci. USA. 82: 795-799.

47. Crapo, J. D., B. E. Barry, P. Gehr, M. Bachofen, and E. R. Weibel. 1982. Cell number and cell characteristics of the normal human lung. Am. Rev. Respir. Dis. 125:332-337.

48. van Furth, R., J. A. Raeburn, and T. L. van Zwet. 1979. Characteristics of human mononuclear phagocytes. Blood. 54:485-500.

49. Blouin, A. 1977. Morphometry of liver sinusoidal cells. In Kupffer cells and other liver sinusoidal cells. E. Wisse and D. L. Knook, editors. Elsevier/North-Holland, Amsterdam. 61-71.

50. Adler, C. P., W. P. Pringlage, and N. Bohm. 1981. DNS-gehalt und Zellzahl in Herz und Leber von Kindern. Vergleichende biochemische, cytophotometrische und histologische Untersuchungen. $\mathrm{Pa}$ thol. Res. Pract. 172:25-41.

51. van oud Alblas, A. B., and R. van Furth. 1979. Origin, kinetics, and characteristics of pulmonary macrophages in the normal steady state. J. Exp. Med. 149:1504-1518.

52. Bitterman, P. B., L. E. Saltzman, S. Adelberg, V. J. Ferrans, and R. G. Crystal. 1984. Alveolar macrophage replication: one mechanism for the expansion of the mononuclear phagocyte population in the chronically inflamed lung. J. Clin. Invest. 74:460-469.

53. Frants, R. R., G. T. Noordhoek, and A. W. Eriksson. 1978. Separator isoelectric focusing for identification of alpha-1-antitrypsin (Pi M) subtypes. Scand. J. Clin. Lab. Invest. 38:457-462.

54. Constans, J., M. Viau, and C. Gouaillard. 1980. Pi M4: an additional Pi M subtype. Hum. Genet. 55:119-121.

55. Thurlbeck, W. M., J. A. Henderson, R. G. Fraser, and D. V. Bates. 1970. Chronic obstructive lung disease: a comparison between clinical, roentgenologic, functional and morphologic criteria in chronic bronchitis, emphysema, asthma and bronchiectasis. Medicine (Baltimore). 49:81-145.

56. Fogh, J., and G. Trempe. 1975. New human tumor cell lines. In Human Tumor Cells In Vitro. J. Fogh, editor. Plenum Press, New York. 115-159.

57. Zuckerman, A. J., P. E. Taylor, J. P. Jacobs, and C. A. Jones. 1970. Chromosome studies of virus-infected semi-continuous human embryonic liver cells. Br. J. Exp. Pathol. 51:92-96.

58. Johnson, W. D., B. Mei, and Z. A. Cohn. 1977. The separation, long-term cultivation, and maturation of the human monocyte. J. Exp. Med. 146:1613-1626.

59. Tucker, S. B., R. V. Pierre, and R. E. Jordon. 1977. Rapid identification of monocytes in a mixed mononuclear cell preparation. J. Immunol. Methods. 14:267-269.

60. Hunninghake, G. W., J. E. Gadek, O. Kawanami, V. J. Ferrans, and R. G. Crystal. 1979. Inflammatory and immune processes in the human lung in health and disease: evaluation by bronchoalveolar lavage. Am. J. Pathol. 97:149-206.

61. Saltini, C., A. J. Hance, V. J. Ferrans, F. Basset, P. B. Bitterman, and R. G. Crystal. 1984. Accurate quantification of cells recovered by bronchoalveolar lavage. Am. Rev. Respir. Dis. 130:650-658.

62. Koren, H. S., S. J. Anderson, and J. W. Larrick. 1979. In vitro activation of a human macrophage-like cell line. Nature (Lond.). 279: 328-331.

63. Breul, S. K., K. H. Bradley, A. J. Hance, M. P. Schafer, R. A.
Berg, and R. G. Crystal. 1980. Control of collagen production by human diploid lung fibroblasts. J. Biol. Chem. 255:5250-5260.

64. Chirgwin, J. M., A. E. Przybyla, R. J. MacDonald, and W. J. Rutter. 1979. Isolation of biologically active ribonucleic acid from sources enriched in ribonuclease. Biochemistry. 18:5294-5299.

65. Cox, R. A. 1968. The use of guanidinium chloride in the isolation of nucleic acids. Methods Enzymol. 12B:120-129.

66. Glisin, V., R. Crkvenjakov, and C. Byus. 1974. Ribonucleic acid isolated by cesium chloride centrifugation. Biochemistry. 13:2633-2637.

67. Ehrenberg, L., I. Fedorcsak, and F. Solymosy. 1976. Diethyl pyrocarbonate in nucleic acid research. Prog. Nucleic Acid Res. Mol. Biol. 16:189-262.

68. Bresser, J., J. Doering, and D. Gillespie. 1983. Quick-blot: selective mRNA or DNA immobilization from whole cells. DNA (NY). 2:243254.

69. Tibbetts, C., K. Johansson, and L. Philipson. 1973. Hydroxyapatite chromatography and formamide denaturation of adenovirus DNA. J. Virol. 12:218-225.

70. Berger, S. L., and C. S. Birkenmeier. 1979. Inhibition of intractable nucleases with ribonucleoside-vanadyl complexes: isolation of messenger ribonucleic acid from resting lymphocytes. Biochemistry. 18:5143-5149.

71. Lehrach, H., D. Diamond, J. M. Wozney, and H. Boedtker. 1977. RNA molecular weight determinations by gel electrophoresis under denaturing conditions, a critical reexamination. Biochemistry. 16:47434751.

72. Carmichael, G. G., and G. V. McMaster. 1980. The analysis of nucleic acids in gels using glyoxal and acridine orange. Methods Enzymol. 65:380-391.

73. Thomas, P. S. 1980. Hybridization of denatured RNA and small DNA fragments transferred to nitrocellulose. Proc. Natl. Acad. Sci. USA. 77:5201-5205.

74. Gunning, P., P. Ponte, H. Okayama, J. Engel, H. Blau, and L. Kedes. 1983. Isolation and characterization of full-length cDNA clones for human $\alpha-, \beta$-, and $\gamma$-actin mRNAs: skeletal but not cytoplasmic actins have an amino-terminal cysteine that is subsequently removed. Mol. Cell. Biol. 3:787-795.

75. Meinkoth, J., and G. Wahl. 1984. Hybridization of nucleic acids immobilized on solid supports. Anal. Biochem. 138:267-284.

76. Munro, H. N. 1966. The determination of nucleic acids. 1966. Methods Biochem. Anal. 14:113-176.

77. Davidson, J. N., I. Leslie, and J. C. White. 1951. The nucleic acid content of the cell. Lancet. $i: 1287-1290$.

78. Cookson, S. L., and D. O. Adams. 1978. A simple, sensitive assay for determining DNA in mononuclear phagocytes and other leukocytes. J. Immunol. Methods. 23:169-173.

79. Alpert, S. E., H. S. Auerbach, F. S. Cole, and H. R. Colten. 1983. Macrophage maturation: differences in complement secretion by marrow, monocyte, and tissue macrophages detected with an improved hemolytic plaque assay. J. Immunol. 130:102-107.

80. Werb, Z., and J. R. Chin. 1981. Biosynthetic radiolabeling of cellular and secreted proteins of mononuclear phagocytes. In Methods for Studying Mononuclear Phagocytes. D. O. Adams, P. J. Edelson, and H. S. Koten, editors. Academic Press, Inc., New York. 861-872.

81. Sugiura, M., S. Hayakawa, T. Adachi, Y. Ito, K. Hirano, and S. Sawaki. 1981. A simple one-step purification of human $\alpha 1$-proteinase inhibitor by immunoabsorbent column chromatography. J. Biochem. Biophys. Methods. 5:243-249.

82. Laemmli, U. K. 1970. Cleavage of structural proteins during the assembly of the head of bacteriophage T4. Nature (Lond.). 227:680-685.

83. Bonner, W. M., and R. A. Laskey. 1974. A film detection method for tritium-labelled proteins and nucleic acids in polyacrylamide gels. Eur. J. Biochem. 46:83-88.

84. Schreiber, G., and G. Howlett. 1983. Synthesis and secretion of acute-phase proteins. In Plasma Protein Secretion by the Liver. H. Glaumann, T. Peters, and C. Redman, editors. Academic Press, Ltd., London. 423-449.

85. Kueppers, F. 1968. Genetically determined differences in the 
response of alphal-antitrypsin levels in human serum to typhoid vaccine. Humangenetik. 6:207-214.

86. Faarvang, H. J., and O. S. Lauritsen. 1963. Increase of trypsin inhibitor in serum during pregnancy. Nature (Lond.). 199:290-291.

87. Ganrot, P. O., and B. Bjerre. 1967. Alpha-1-antitrypsin and alpha2-macroglobulin concentration in serum during pregnancy. Acta Obstet. Gynecol. Scand. 46:126-137.

88. Laurell, C. B., S. Kullander, and J. Thorell. 1967. Effect of administration of a combined estrogen-progestin contraceptive on the level of individual plasma proteins. Scand. J. Clin. Lab. Invest. 21:337-343.

89. Lieberman, J., C. Mittman, and J. R. Kent. 1971. Screening for heterozygous alpha 1-antitrypsin deficiency. III. A provocative test with diethylstilbestrol and effect of oral contraceptives. J. Am. Med. Assoc. 217:1198-1206.

90. Lieberman, J., and C. Mittman. 1973. Dynamic response of $\alpha 1$ antitrypsin variants to diethylstilbestrol. Am. J. Hum. Genet. 25:610617.

91. Eriksson, S. 1983. The effect of Tamoxifen in intermediate alphalantitrypsin deficiency associated with the phenotype PiSZ. Ann. Clin. Res. 15:95-98.

92. Colten, H. R. 1984. Expression of the MHC class III genes. Philos. Trans. $R$. Soc. Lond. B306:355-366.

93. Cole, F. S., H. S. Auerbach, G. Goldberger, and H. R. Colten. 1985. Tissue-specific pretranslational regulation of complement production in human mononuclear phagocytes. J. Immunol. 134:2610-2616.
94. Weiel, J. E., D. O. Adams, and T. A. Hamilton. 1984. Murine monocytes express transferrin receptors: evidence for similarity to inflammatory macrophages. Cell. Immunol. 88:343-349.

95. Andreesen, R., J. Osterholz, H. Bodemann, K. J. Bross, U. Costabel, and G. W. Lohr. 1984. Expression of transferrin receptors and intracellular ferritin during terminal differentiation of human monocytes. Blut. 49:195-202.

96. Hirata, T., M. Brantly, J. F. Mornex, P. Bitterman, and R. G. Crystal. 1985. Transferrin receptor gene expression during the maturation of blood monocytes to tissue macrophages. Clin. Res. 33(Pt 2):379A. (Abstr.)

97. Wewers, M. D., S. I. Rennard, A. J. Hance, P. B. Bitterman, and R. G. Crystal. 1984. Normal human alveolar macrophages obtained by bronchoalveolar lavage have a limited capacity to release interleukin-1. J. Clin. Invest. 74:2208-2218.

98. Sztein, M. B., P. S. Steep, H. M. Johnson, and J. J. Oppenheim. 1984. Regulation of human peripheral blood monocyte DR antigen expression in vitro by lymphokine and recombinant interferons. J. Clin. Invest. 73:556-565.

99. Leslie, C. C., R. A. Musson, and P. M. Henson. 1984. Production of growth factor activity for fibroblasts by human monocyte-derived macrophages. J. Leukocyte Biol. 36:143-159.

100. Fulmer, J. D., W. C. Roberts, E. R. Von Gal, and R. G. Crystal. 1977. Small airways in idiopathic pulmonary fibrosis: comparison of morphologic and physiologic observations. J. Clin. Invest. 60:595-610. 